TITLE:

\title{
MALE FIRST PLEOPODS OF THE MAJID BRACHYURANS CHIONOECETES OPILIO (O. FABRICIUS) AND C. JAPONICUS RATHBUN FROM THE JAPAN SEA
}

\author{
$\operatorname{AUTHOR}(\mathrm{S})$ :
}

Nishimura, Saburo

\section{CITATION:}

Nishimura, Saburo. MALE FIRST PLEOPODS OF THE MAJID BRACHYURANS

CHIONOECETES OPILIO (O. FABRICIUS) AND C. JAPONICUS RATHBUN FROM THE JAPAN SEA. PUBLICATIONS OF THE SETO MARINE BIOLOGICAL LABORATORY 1967, 15(3): 165 171

\section{ISSUE DATE:}

1967-10-30

URL:

http://hdl.handle.net/2433/175469

RIGHT: 


\title{
MALE FIRST PLEOPODS OF THE MAJID BRACHYURANS CHIONOECETES OPILIO (O. FABRICIUS) AND $C$. JAPONICUS RATHBUN FROM THE JAPAN SEA ${ }^{1}$
}

\author{
SABURO NISHIMURA \\ Seto Marine Biological Laboratory, Sirahama
}

With 10 Text-figures

The boreo-arctic brachyuran genus Chionoecetes KR $\phi \mathbf{Y E R}, 1838$ (Crustacea: Decapoda) is represented by two species in the Japan Sea, viz. C. opilio (O. FABRicius, 1780) and C. japonicus RAtubun, 1932. The former, often referred to as C. opilio elongatus Rathbun, 1924 by some authors, is a species from a moderate depth, mainly $150 \mathrm{~m}$ to $350 \mathrm{~m}$, while the latter, treated by Russian authors under the name C. angulatus bathyalis Derjugin \& Kobjakova, 1935, is an inhabitant of much greater depths, ranging from $450 \mathrm{~m}$ or thereabout down to $2500 \mathrm{~m}$ but mostly from $700 \mathrm{~m}$ to $1000 \mathrm{~m}$. Both species occupy each a very important situation in the bottom community in respective ranges in the Japan Sea (Nishimura 1966).

Since Duvernoy (1850) and especially Brocahr (1875) noticed the morphological difference of the male pleopod or the so-called 'penis' in various brachyuran families, genera and species, numerous works have been done along the similar line, and the papers published prior to 1940 were all summarized in STEPHensen's (1946). As to the morphology of the same appendage in the members of Chionoecetes, GARTH (1958) dealt with four species from the eastern North Pacific, viz. C. buirdi Rathbun, tanneri Rathbun, opilio (O. FABRIcius) and angulatus RAthbun. He examined, however, only one or two, mostly young or immature, specimens of each species, and thus nothing was given as to the morphological change of the appendage with growth. So far as I am aware, nothing has been reported on the morphology of the same structure of C.japonicus, either. The present paper is prepared to give the morphology, especially its developmental changes, of the male first pleopod of $C$. opilio and $C$. japonicus from the Japan Sea. The present examination was made as the first step in the comparative study of the appendage referred to throughout all the species of the genus distributed in the Far-Eastern seas and the North Pacific.

The material treated in this paper consists of two samples: the specimens of C. opilio were collected by trawl from the depth of $320 \mathrm{~m}$ in Wakasa Bay off Tsuruga

1) Contributions from the Seto Marine Biological Laboratory, No. 468.

Publ. Seto Mar. Biol. Lab., XV (3), 165-171, 1967. (Article 9) 
in February 1966, while those of C. japonicus were trapped on the bottom 800 to $1100 \mathrm{~m}$ deep off Nô, south of Niigata (cf. Mizusawa 1965), in the season from March to May 1966.

I am much indebted to Mr. Rokurô Mizusawa of the Fisheries High School at Nô, Niigata Prefecture, and to Mr. Tôru Yasuda of the Fukui Prefectural Fisheries Experimental Station at Tsuruga for their kind help in collecting the samples. Cordial thanks are also due to Prof. Huzio Utinomi and Dr. Takasi Tokioka of our laboratory for their kindness in reading the manuscript.

\section{Descriptions}

Chionoecetes opilio (Figs. 1-6).

The first pleopod in the fully-grown male is lanceolate with a bulbous base, smoothly bending and gradually tapering to an acute tip which is abruptly reflexed; longitudinally grooved from the inner edge of the base to the neck of the reflexed tip (Fig. 1). Around the abdominal surface (for terminology used in describing the structure and orientation of the male first pleopod in brachyurans, see Tweedie 1940 and Garth 1958) of the neck of the tip and continuously down to the outer ridge along the longitudinal groove, there are a number of spinose, pointed filaments
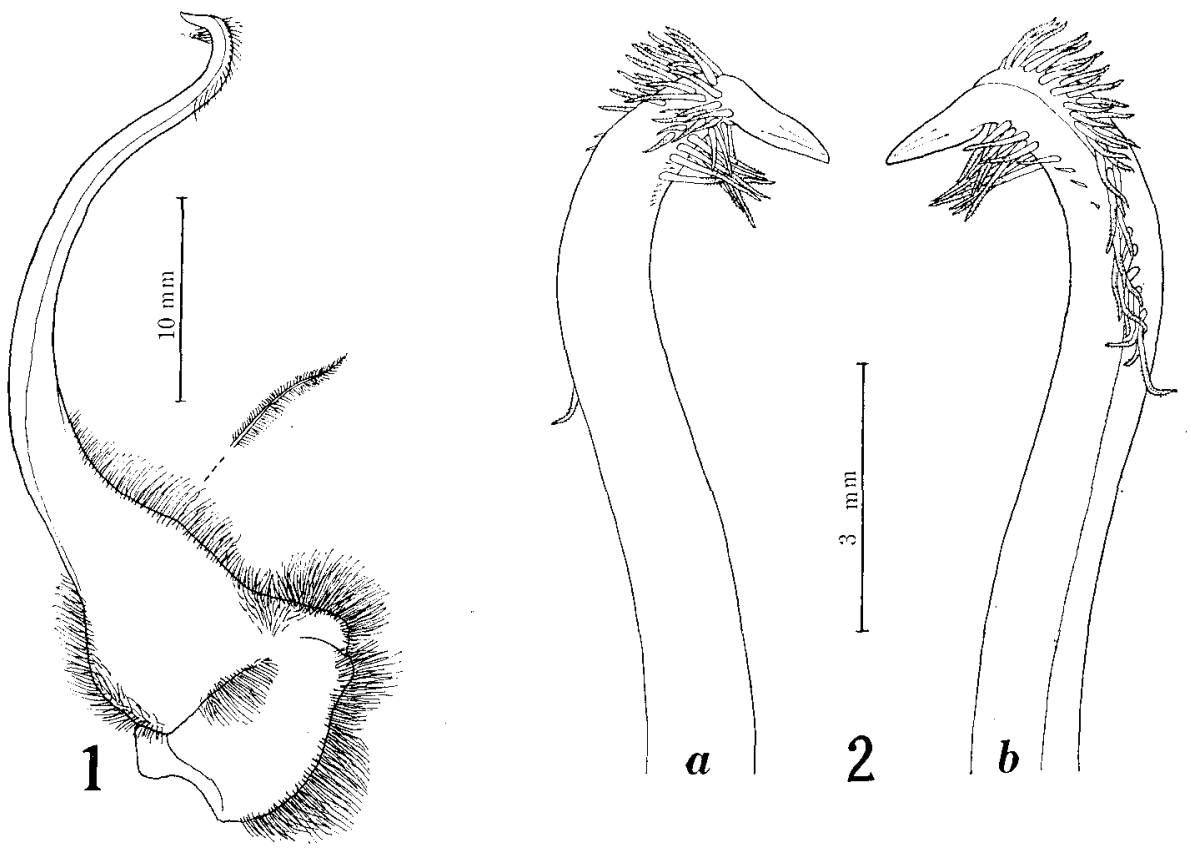

Figs. 1-2. Male first pleopod of a fully matured specimen (140 $\mathrm{mm}$ in carapace length) of Chionoecetes opilio. 1.-Total aspect (sternal view) of the right pleopod; 2.-Tip of the same ( $a$ abdominal, $b$ sternal view). 
(Fig. 2) which can be grouped into three as follows. The first group includes the filaments arranged along the longitudinal groove up to the abdominal surface of the neck, proximal filaments being inserted in a single row, but distal ones in two or three rows; the second group is a tuft of somewhat shorter filaments inserted at the inner edge of the abdominal surface of the neck; and the third group consists of two parallel rows of filaments on the inner concavity of the neck. Hereafter, these filament groups will be represented respectively as I, II and III. The group I may further be divided for convenience' sake into $I_{s}$ and $I_{m}$ according to the sites of a single row and multiple rows, and the group III similarly into III $_{\mathrm{a}}$ and III $_{\mathrm{s}}$ according to the abdominal and sternal situations of respective rows. The number of filaments included in each group thus defined in ten specimens is shown in Table 1.

Table 1. Distribution of filaments in respective groups on the distal part of the male first pleopod in Chionoecetes opilio from the Japan Sea.

Arabic numerals indicate the number of large filaments, while Roman numerals show that of rudimentary ones.

\begin{tabular}{c|c|c|c|c|c|c}
\hline \hline \multirow{2}{*}{$\begin{array}{c}\text { Specimen } \\
\text { no. }\end{array}$} & $\begin{array}{c}\text { Carapace } \\
\text { length }\end{array}$ & \multicolumn{5}{|c}{ Filament groups } \\
\cline { 2 - 7 } & $\mathrm{I}_{\mathbf{s}}$ & $\mathrm{I}_{\mathrm{m}}$ & $\mathrm{II}$ & $\mathrm{III}_{\mathrm{a}}$ & $\mathrm{III}_{\mathrm{s}}$ \\
\hline 1 & $140 \mathrm{~mm}$ & 9 & 24 & 12 & $11+\mathrm{vii}$ & $5+\mathrm{iii}$ \\
2 & 140 & 12 & 21 & 15 & $13+\mathrm{vii}$ & $5+\mathrm{iii}$ \\
3 & 133 & 12 & 19 & 10 & 7 & $6+\mathrm{ii}$ \\
4 & 100 & 7 & 21 & 13 & $12+\mathrm{vi}$ & $12+\mathrm{iii}$ \\
5 & 86 & 13 & 20 & 18 & $6+\mathrm{iv}$ & $6+\mathrm{ii}$ \\
6 & 74 & 10 & 25 & 15 & $12+\mathrm{ii}$ & $7+\mathrm{viii}$ \\
7 & 49 & 11 & 28 & 16 & $9+\mathrm{ii}$ & $9+\mathrm{iv}$ \\
8 & 38 & 9 & 24 & 8 & 12 & $\mathrm{i}$ \\
9 & 30 & 8 & 22 & 5 & $9+\mathrm{i}$ & $1+\mathrm{i}$ \\
10 & 30 & 10 & 19 & 5 & 12 & vi \\
\hline
\end{tabular}

It is seen from the table that in individuals larger than about $40 \mathrm{~mm}$ in carapace length the number of filaments of each group is rather constant, while in smaller specimens the groups II and $\mathrm{III}_{\mathrm{s}}$ have each decidedly fewer filaments than in adults though the remaining groups are already provided with filaments as many as in adults. Thus, it is supposed that the male crab reaches the definitive state as to the filament armature of this appendage when the carapace is grown to approximately $45 \mathrm{~mm}$ in length.

Developmental change in the shape of the distal part of the male first pleopod is shown in Figs. 3 to 6 . In younger individuals the longitudinal groove is shallow and opens widely, but it becomes deeper and the lateral edges approach each other as the animal grows and at last form together a tightly closed groove. The tip becomes gradually elongated and pointed with the growth. On the whole, it appears that 

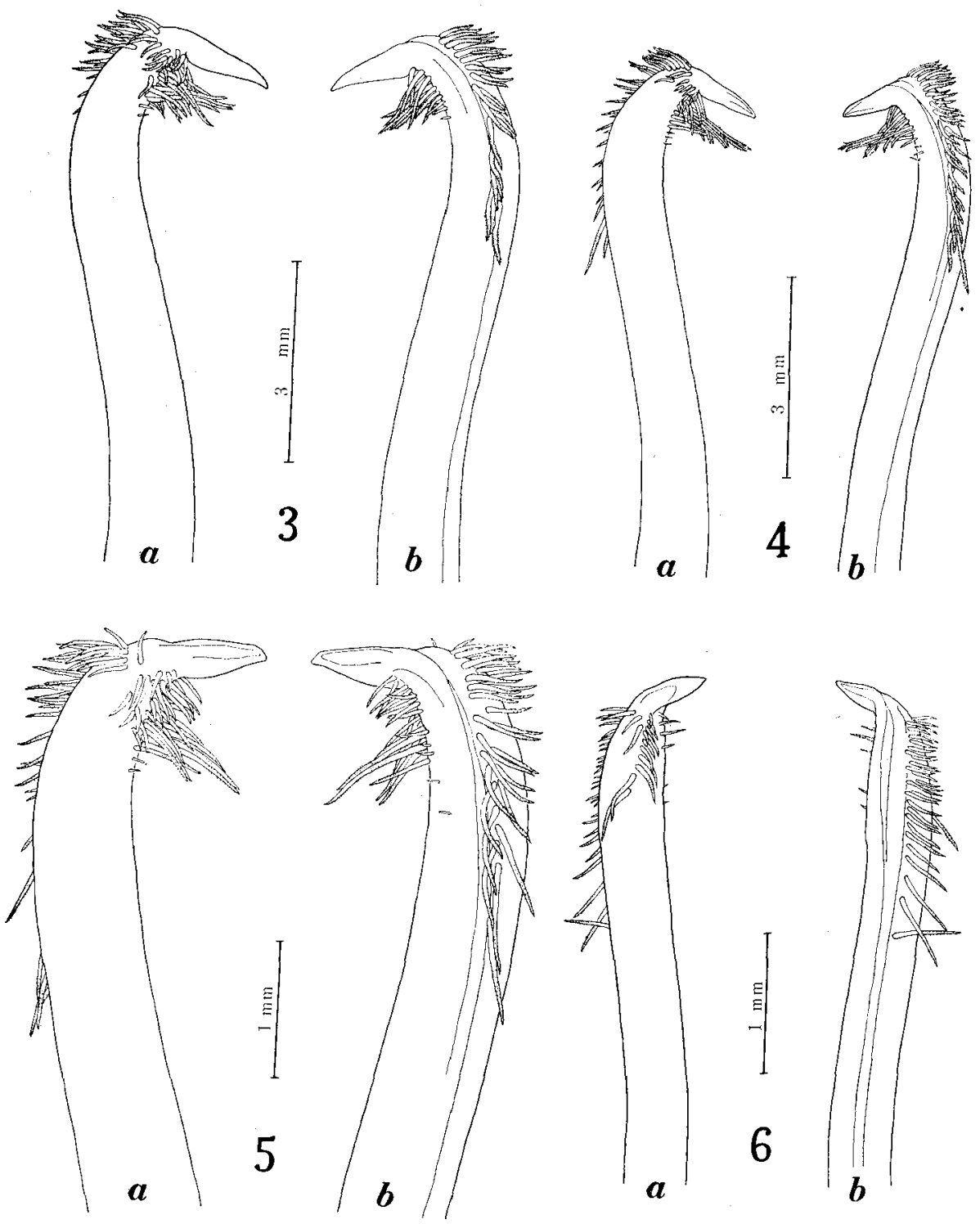

Figs. 3-6. Developmental change in the external feature of the tip of right first pleopod in Chionoecetes opilio. 3.-100 $\mathrm{mm} ; 4 .-74 \mathrm{~mm} ; 5 .-49 \mathrm{~mm} ; 6 .-30 \mathrm{~mm}$ in carapace length. $a$ abdominal, $b$ sternal aspect. 
the external morphology of the pleopod is completed in the individuals with the carapace $80 \mathrm{~mm}$ or so in length.

\section{Chionoecetes japonicus (Figs. 7-10).}

Since no specimens of this species smaller than $90 \mathrm{~mm}$ in carapace length were available, only the adult morphology is explained here.

The general structure is similar to that of $C$. opilio, but some differences are noted in several important points between the two species. The pleopod is bent a little more strongly and the distal reflexion seems rather gentle in C. japonicus. The tip is longer and distally somewhat recurvate in the present species, while it is rather short and straight in $C$. opilio. The appearance of the filament groups is also different: in the present species the filaments in groups $I_{m}$ and $I I I_{a}$ are much more abundant than in C. opilio, while the group III $_{\mathrm{s}}$ is quite devoid of any large filaments but represented only occasionally by a few rudimentary ones inserted at somewhat displaced positions (Table 2 and Fig. 8 ).

Table 2. Distribution of filaments in respective groups on the distal part of the male first pleopod in Chionoecetes japonicus from the Japan Sea.

Arabic numerals indicate the number of large filaments, while Roman numerals show that of rudimentary ones.

\begin{tabular}{c|c|c|c|c|c|c}
\hline \multirow{2}{*}{$\begin{array}{c}\text { Specimen } \\
\text { no. }\end{array}$} & $\begin{array}{c}\text { Carapace } \\
\text { length }\end{array}$ & \multicolumn{5}{|c|}{ Filament groups } \\
\cline { 2 - 6 } & $\mathbf{I}_{\mathbf{s}}$ & $\mathbf{I}_{\mathbf{m}}$ & $\mathrm{II}$ & $\mathrm{III}_{\mathbf{a}}$ & III $_{\mathbf{s}}$ \\
\hline 1 & $149 \mathrm{~mm}$ & 8 & 35 & $\mathbf{8}$ & $22+\mathrm{xvi}$ & $\mathrm{iv}$ \\
2 & 133 & $9+\mathrm{ii}$ & 40 & 9 & $21+\mathrm{ii}$ & $\mathrm{i}$ \\
3 & 127 & 7 & 34 & 8 & $19+\mathrm{iii}$ & 0 \\
4 & 125 & 8 & 32 & 11 & $24+\mathrm{v}$ & 0 \\
5 & 118 & $8+\mathrm{i}$ & 35 & 7 & $18+\mathrm{vii}$ & 0 \\
6 & 107 & $14+\mathrm{i}$ & 33 & 9 & $17+\mathrm{iii}$ & viii \\
7 & 103 & $6+\mathrm{iii}$ & 39 & 10 & $20+\mathrm{i}$ & iii \\
8 & 95 & 18 & 35 & 11 & $19+\mathrm{ii}$ & 0 \\
9 & 94 & $11+\mathrm{ii}$ & 24 & 8 & $16+\mathrm{iii}$ & 0 \\
10 & 91 & $9+\mathrm{i}$ & 33 & 9 & $16+\mathrm{iii}$ & 0 \\
\hline
\end{tabular}

The developmental change can be seen partially as to the shape of the distal part of the pleopod even in the specimens at disposal. In younger specimens (Fig. 10 ), the tip is more slender and nearly straight as in the sub-adult of C. opilio; in fully-matured specimens (Fig. 8), on the other hand, it is more or less extended on one plane to be slightly flattened and recurvate. As seen in Table 2, the number of filaments of the group $I_{s}$ is somewhat variable as compared with those of other groups, although it is not known at present whether or not this is a developmental change. 

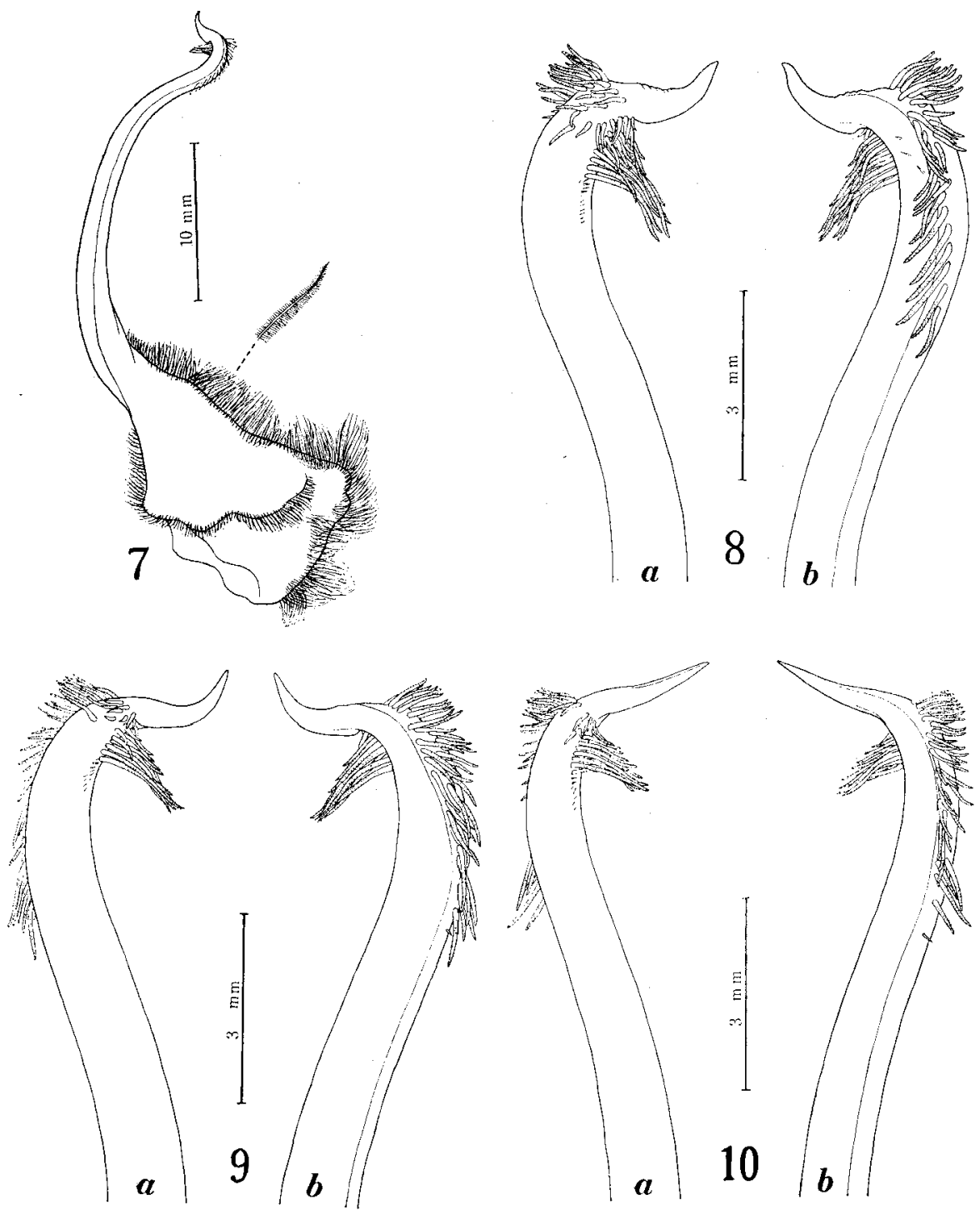

Figs. 7-10. Male first pleopod of Chionoecetes japonicus. 7.-Total aspect (sternal view) of the right pleopod of a fully matured specimen $149 \mathrm{~mm}$ in carapace length; 8.-Tip of the same; $9 \& 10$.-Tip of the right pleopod of the specimens respectively $117 \mathrm{~mm}$ and $91 \mathrm{~mm}$ in carapace length. $a$ abdominal, $b$ sternal aspect. 


\section{Discussion}

As mentioned above, there is a considerable difference in the structure of the male first pleopod between Chionoecetes opilio and C. japonicus. So far as the number and arrangement of filaments on the distal part are concerned, the structure of the appendage of $C$. opilio resembles roughly that of $C$. bairdi distributed off the west coast of North America. On the other hand, however, according to the illustration given by GARTH (1958), the sub-adult of the latter species has only three large filaments at the site of the group $I I I_{s}$ and the tip is slightly recurvate; such features are related more or less to those of $C$. japonicus. The structure of the pleopod figured by GARTH (1958) for a male specimen of C. opilio $69.3 \mathrm{~mm}$ in carapace length, collected off Pribilof Islands, Alaska (Albatross station 3440), essentially coincides with that of the same species from the Japan Sea. Thus, so far as the structure of the male first pleopod is concerned, it does not seem likely that $C$. opilio from the Japan Sea, often treated as the subspecies elongatus, and C. bairdi are respectively to be placed in an analogous taxonomic situation in relation to the typical form of $C$. opilio which is distributed in the Bering Sea and the North Atlantic.

As is noted especially in C. opilio, a considerable change takes place in the structure of the pleopod with growth. Thus, the comparison of the structure among related species has to be made on the same level of development, preferably of the adult stage.

\section{REFERENCES}

Brocchi, P. 1875. Recherches sur les organes génitaux mâles des Crustacés Décapodes. Ann. Sci. Nat., Zool., sér. 6, vol. 2, pp. 1-131, pls. XIII-XIX.

Duvernoy, G.L. 1850. Fragments sur les organes de génération de divers animaux. Mém. Acad. Sci. Paris, vol. 23, pp. 105-299.

Garth, J.S. 1958. Brachyura of the Pacific coast of America: Oxyrhyncha. Allan Hancock Pacif. Exped., vol. 21, pp. i-xii, 1-854.

Mrzusawa, R. 1965. The fishing and the study of living of Chionoecetes japonicus RathBun. Zenkoku Kôtôgakkô Suisan Kyôiku Kenkyû Kaihô, no. 5, pp. 290-303. (In Japanese).

Nishimura, S. 1966. The zoogeographical aspects of the Japan Sea, pt. III. Publ. Seto Mar. Biol. Lab., vol. 13, pp. 365-384.

Stephensen, K. 1946. The Brachyura of the Iranian Gulf. With an appendix: the male pleopoda of the Brachyura. Dan. Sci. Invest. Iran, pt. IV, pp. 57-237.

Tweedie, M.W.F. 1940. New and interesting Malaysian species of Sesarma and Utica (Crustacea, Brachyura). Bull. Raffles Mus., Singapore, no. 16, pp. 88-113, pl. XXIV. 